\title{
Differential Subject Marking in Arawakan Languages: Distribution and Origins
}

\author{
Swintha Danielsen \\ Urubichá, Guarayos, Bolivia \\ swintha@hotmail.com \\ Tom Durand \\ Postdoctoral researcher, Structure et Dynamique des Langues (SeDyL) \\ laboratory, UMR 8202 CNRs, Villejuif, France \\ tom.durand@inalco.fr
}

\begin{abstract}
This paper is a comparison of nine Arawakan languages sharing a rare phenomenon in the Americas: differential subject marking. We argue that the languages involved display a group of predicates with oblique case marking on the subject, similar to the subject-like obliques in Icelandic and Hindi. Comparison with bivalent constructions provides a strong argument for the diachronic process of objects gradually acquiring subject properties. In addition, we discuss the distribution of this oblique marking and object marking in some of the Arawakan languages. This paper shows that these two marking strategies are in fact complementary; the existence of these two markings allows expressing semantico-pragmatics subtleties. Thus, it illustrates a specific realization of the differential marking of the subject in non-accusative languages. Examining the possibilities of language contact with non-Arawakan languages, such as Tukanoan or Witotoan languages, or between Arawakan languages, especially in the NorthWestern region of Amazonia, we conclude that this phenomenon is inherited in the Arawakan language family, considering the absence of other languages with such differential marking in South America and the attestations of this phenomenon in Arawakan languages as many as 500 years ago.
\end{abstract}

\section{Keywords}

differential subject marking - patientive marking - alignment - Arawakan languages - diachrony - language contact

(C) SWINTHA DANIELSEN AND TOM DURAND, 2020 | DOI:10.1163/19552629-bja10005

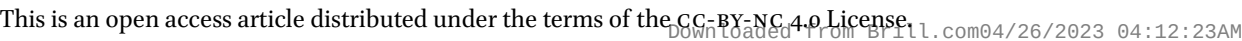


The Arawakan family constitutes one of the largest linguistic families of the Americas, with more than forty languages still spoken by around 500,000 speakers, if we take into account the greatest estimations (Aikhenvald, 1999: 72). The sociolinguistic status of the particular languages changes significantly.

Arawakan languages are predominantly agglutinating and may tend to polysynthesis. The particularly rich verbal morphology is mostly suffixal. Concerning the alignment, these languages depict every type of split intransitivity, as shown in Durand, 2016. The Arawakan language family is usually divided into Northern and Southern Arawakan (cf. Aikhenvald, 1999), and then further into subgroups that cluster according to their grammatical similarities. Southern Arawakan languages tend to be more complex in their morphology, allowing, as argued above, for the marking of the direct object on the verb and for various applicative derivations.

For the broader understanding of argument marking in Arawakan languages, it is relevant to study one specific phenomenon, examined in this paper, namely differential subject marking (DSM) present in nine of forty Arawakan languages. As will be described in the next section, most of the languages of the Arawakan family, which is one of the largest language families of South America, are characterized by split subject marking (split intransitivity), where the subject may be marked like an object under certain conditions, e.g. more state-like or patient-like characteristics of the subject. This prompts us to wonder what would be the motivation for these languages to use an additional differentiation of subject marking. Indeed, to grasp the functionality of such phenomenon would be a precious element to understand its development or even its propagation amongst the Arawak family. In DSM in Arawakan languages, subjects are marked by oblique case marking or adpositions (Danielsen 2011b). In other words, it is pertinent to analyze the necessity - or the advantage - of using a non-canonical marking rather than a canonical marking. Moreover, as explained by Givón (2001), DSM is mostly present in NominativeAccusative languages, more precisely where the subject is not very agent-like. Consequently, determining the reason of the existence of DSM within the Arawak family is necessary to understand its propagation and upholding and is as crucial as determining the origin of this phenomenon. Why use an oblique mark to encode the subject, whereas in the split system, the subject can be marked like an object to specify its less agent-like semantics? To answer this question, we first show the canonical encodings of arguments in Arawakan 
languages in Section 2. Then, in Section 3, we list the inventory of languages characterized by DSM, identify the oblique cases that are used, and explain the distribution between oblique cases and the object marking. In Section 4, we discuss the possible origins of this oblique marking from a synchronic and diachronic perspective, by viewing the impact of inherited and contact features.

\section{Typical Argument Marking in Arawakan Languages and Variations}

Arawakan languages show many similarities in argument marking on predicates. The personal affixes, which have played a major role in identifying the language family in the first place (Gilij, 1780-84), figure dominantly in the common marking of core arguments. These affixes are also used in non-verbal predicates to mark the possessor on nouns (1) and to mark the subject of active intransitive and transitive verbs as in (2) and (3). The person marks will be named set $\mathrm{A}$ and $\mathrm{B}^{1.2}$ and, for data from other authors, we will put these glosses into square brackets:

(1) nu-ti

Piapoco (Northern Arawakan) ${ }^{3}$

A1SG-eye

'my eye'

(2) nu-tani-ka

A1SG-talk-REAL

'I talk.'

(3) nu-maida-ni

A1SG-call-B3

'I called him/her/them.'

(Durand, 2013)

1 We chose to name set A and set B - A and B in the glosses - the person markers used on the one hand for the single argument of some intransitive verbs and for the agent of transitive verbs, and on the other hand, for the single argument of some intransitive verbs and for the patient of transitive verbs, respectively. This choice is the most neutral and does not bring confusion, as the pairs subjective/objective and agentive/patientive are connoted syntactically and semantically, respectively.

2 For an easier reading, we chose to not use these glosses when the set $\mathrm{A}$ is being used as a support for oblique marks or postpositions.

3 In the Appendix, a table summarizes all DSM features of the languages with their Iso $693^{-} 3$. 
Direct object marking on transitive verbs by personal suffixes is mostly found in the Southern Arawakan branch (4) (Durand, 2016: 741-746). In the Northern branch, the personal suffixes compete with bound pronouns postponed to the predicate (5). In addition, both branches contain languages where personal suffixes can be substituted by free pronouns or other types of NPs.

The object suffixes may slightly differ from the prefix forms, but it is suggested that both sets originate from the same set of affixed (bound) pronominal forms (cf. Danielsen, 2011a).

(4) i-shiya-k-a-na

Ashéninka Pajonal (Southern Arawakan) A3SG.M-run-PFV-REAL-B1SG

'He makes me run.' (Durand, 2012)

$\begin{array}{lll}\text { (5) i-wawa } & i \text {-kaka } & \text { nua } \\ \text { A3sG-want } & \text { 3sG-see } & \text { B1SG }\end{array}$

'He wants to see me.'

(Durand, 2013)

Furthermore, in a majority of Arawakan languages, a subclass of predicates marks their subject in the object slot, be it with a suffix or a postposed pronoun. This statement is based on the fact that the person affixes/clitics order is $\mathrm{s}-\mathrm{V}-\mathrm{o}$, even if word order is quite diverse in the Arawak family (Aikhenvald, 1999). The phenomenon has been referred to as split intransitivity or split-S system (e.g. in Gildea, 200o), since there is a split between intransitive verbs, the ones taking the subject marking, and the others taking the object marking. The predicates of the second class vary according to its motivations. In some languages, this marking is motivated by the semantics of the verb and applied on stative intransitive predicates like in Piapoco (6), whereas in other languages, split intransitivity is conditioned by grammatical or pragmatical factors, as in Ashéninka of the Pajonal (7). Whatever the case, the same marking is used, as being shown by examples (6) and (7):

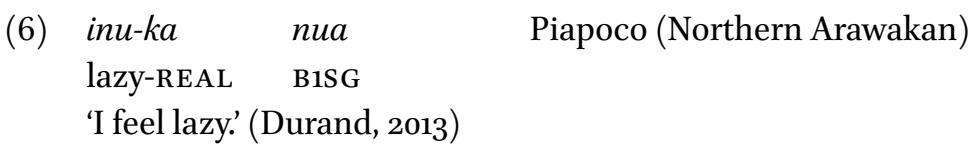

(7) awawe-t-ak-i-na Ashéninka Pajonal (Southern Arawakan) swollen-EP-PFV-REAL-B1SG 'I have an inflammation.'

(Durand, 2012) 
Apart from Tariana, which is an exception, Arawakan languages do not show proper case systems, i.e. marking on the core arguments of a predicate.

It has been shown (Ramirez, 1992; Danielsen, 2007) that non-verbal predicates, in general, tend to take this kind of argument marking, which also holds for a vast majority of Northern Arawakan languages, languages that normally do not make much use of argument marking in the suffix position (8). In the case of a possessed noun, we may then indeed find pronominal marking of two kinds and on two levels on one predicate: prefixal referring to the possessor, and suffixal referring to the single argument (9).

waituranawi-na

man-[B]11SG

'I am a man.'

(9) $\boldsymbol{\phi} \dot{\boldsymbol{t}}$-tsinawi-na

[A]2SG-wife-[B]11SG

'I am your wife.'
Xiriâna-(Northern Arawakan) ${ }^{4}$

(Ramirez, 1992: 31)

Furthermore, some languages openly give the possibility to mark a single argument like the agent or the patient of a transitive verb for the same predicate, depending on semantic, pragmatic or morphosyntactic properties of the argument. Compare how Garifuna uses set B marking by a suffix referring to the single argument (10) for the general act of taking a walk or when a walk has been done some indefinite time ago, whereas it uses set A subject marking by a prefix (11) when the walk is delimited and directed, thus in a way made more punctual.

(10) ebuga-ti-na walk-M ${ }^{5}-[\mathbf{B}] \mathbf{1 S G}$

'I walk (in the sense of having gone for a walk).'
Garifuna (Northern Arawakan)

(lit. I am a walker.)

4 In this paper, we do not refer again to this language, however, its Iso-code is xir, and the name Ramirez (1992) uses is Bahuana.

5 The -ti morpheme is quite difficult to gloss. Haurholm-Larsen (2016) considers it is a verbal aspect marker, whereas Munro (2007) and Stark (2013) argue that it has fused with the person suffixes. Due to the lack of first hand data, we chose to not decide between these two interpretations and to make reference to its non-finite heritage, since - $t i$ is historically a nominalizer, hence, the gender mark gloss. This point will be explained in more details in Section 3.2. 


\section{(11) n-ebugu-ba}

leskwela haruga

[A]1SG-walk-FUT school tomorrow

'I will walk to school tomorrow.'

Indeed, the word order for person affixes or clitics within the family is s-V-o, even if most Arawakan languages exhibit discourse-configurational word order (Aikhenvald, 1999: 98, Facundes, 2000, for Apurinã, Hanson, 2010, for Yine, Brandão, 2014, for Paresi). This last characteristic explains why a few Arawakan languages display sometimes the object before the subject, especially in Apurinã and Terena (Facundes, 2000: 546, Neubaner, 2012: 81). This is why, in transitive constructions, an argument postposed to the verb and at the final position of the sentence is generally considered the object, whereas the preposed argument is generally interpreted as the subject. In addition, a conditioned distribution of argument encoding in word order in intransitive constructions is observable. More precisely, in languages showing split intransitivity, the single argument is placed differently according to the marking type used, preposed to the verb for set A, postposed for set B. This claim can be proved by examples of various Arawakan languages known as having split intransitivity and by the "active word order" expression (Goergens, 2011: 33), where the word order would be SaV or VSo, depending on the semantics of the verb.

Arawakan languages employ postpositions for the marking of oblique arguments. For all of them, there are two different ways to use postpositions: either they attach directly to the noun, as does the locative postposition, or they get a prefix, similar to that of possessed nouns, refering to their argument. Postpositions differ with respect to their productivity. Some of them can have broader semantics than others, and therefore, some oblique cases are also more grammaticalized than others. The benefactive position - see (12) and (13) - tends to be a typical grammaticalized oblique, considering that the recipient is often the third argument directly related to an event (ditransitive verbs, as in (12), derived benefactive verbs, as in (13)):

$$
\begin{array}{ll}
\emptyset=\text { zakaihaka-ita } & \text { no=hiye } \\
{[\mathrm{A}] 3 \mathrm{SG}=\text { tell.story-IPFV }} & \text { 1sg=LOC/BEN }
\end{array}
$$

Paresi (Southern Arawakan)

'She told the story to me.'

(Brandão, 2014: 120)

6 We will slightly adapt the glosses to the conventions of this paper using square brackets indicating the absolutive pattern. 
$\begin{array}{lll}\text { (13) } & \text { buchá-güd-uwa-ti } & t \text {-uwágu Darcy Garifuna (Southern Arawakan) } \\ \text { tired-CAUS-PASs-[B]3M } & \text { 3F-BEN } & \text { Darcy }\end{array}$ 'Darcy was made tired.'

(Munro, 2007: 129)

Object marking in Arawakan languages interacts with the fact that verbs also have a rich applicative morphology, which may change any oblique argument into a direct object (Danielsen, 2011b). Direct objects, in general, do not get any marking when they are explicit NPs in the clause, but occur as bare NPs. The position of the NP as post-verbal may be a hint at the semantic role, however the argument itself remains indistinguishable from explicit subject NPs. ${ }^{7}$

As we have seen in this section, the subject of an intransitive verb can be referred to by set A or set B marking. However, these kinds of canonical marking are confronted with another variation of marking the unique argument, namely by oblique marking, which is why we focus on the latter in the following sections, sometimes taking into account the set B if its realization affects the DSM.

\section{Manifestation of the Phenomenon of DSM}

In typology, differential subject marking (DSM) is considered to be the use of a different kind of marking to encode the argument of a monovalent predicate, in comparison to a canonical marking. Nevertheless, since most of the Arawakan languages show split intransitivity, ${ }^{8}$ they use either the set A or the set $\mathrm{B}$ to encode the subject of monovalent predicates. Then, we will refer to DSM as the non-canonical marking of the subject of monovalent predicates; the canonical marking referring to set $\mathrm{A}$ and set $\mathrm{B}$. This section describes what characterizes this phenomenon on semantic, morphological, syntactic, and category-specific grounds; especially in Section 3.4 where we will show how DSM can be a complement to split intransitivity.

\subsection{Language Sample}

DSM is mostly present in Arawakan languages of the North-West of Amazonia, near the border between Colombia, Venezuela and Brazil; that is to say, it concerns mostly the languages Kurripako, Piapoco, Achagua, Tariana, Yukuna and

7 And subject NPs also occur frequently in post-verbal position.

8 All of the languages in the sample show split intransitivity, although this phenomenon may greatly differ from one language to another. 
Baniva del Guainía, all of them being closely-related languages, except Baniva del Guainía, which is from another branch of Northern Arawakan languages. ${ }^{9}$ Moreover, DSM is also found in Garifuna, from the Caribbean group, and Paresi, a Mato Grosso language - the latter being a representative of the Southern Arawakan branch. After the general synchronic comparison, Garifuna will also be contrasted to its ancestor language of the $18^{\text {th }}$ century, the so-called Island Carib. Apart from Achagua, all of the listed languages make use of split intransitivity - which is why DSM does not seem to be a strategy to supplant the split intransitivity phenomenon. For this paper, we rely both on published data and on data Durand has gathered in Colombia and Venezuela for Baniva del Guainía, Kurripako, Piapoco, Yukuna. ${ }^{10}$

\subsection{Overview of Oblique Marking used for DSM}

This work is about a group of intransitive predicates where the subject is marked by an oblique case or an adposition. Generally, this is the most common marking for them, whereas set B occurs sometimes as an alternative. In some languages, like Piapoco, even several oblique markers can occur with one and the same predicate, or be distributed between different types of predicates that show DSM; a point detailed in Section 3.4. The variation between oblique markers and set B is reflected upon in subsection 3.4, whereas a table in the appendix will resume the distribution between these different markers. In this and in the next subsection, we will present the used oblique markers and the lexical extension of the group of predicates that occur in constructions with these markers. The most common oblique marker is the dative, but other oblique cases also appear. In the most typical situation, the predicate is in the initial position whereas the subject occurs post-verbally, that is, in the same position that an object or a set $\mathrm{B}$ subject would generally take, as in the following example of Piapoco:

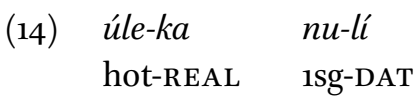

Piapoco (Northern Arawakan)

'I am hot.'

(Durand, 2013)

In Tariana, DSM occurs when a single argument is marked by the oblique suffix -na, glossed as 'овј (object case)', a suffix that assembles the dative and

9 We specify that this language is the same as what Aikhenvald (1998) calls Warekena of Xie. The Iso-code that has been applied to it (gae), is therefore confusing. See also González Ñánez (2005) for a detailed discussion on names for these languages and mistakes in assignments, as e.g. in Aikhenvald (1998).

10 The sources are indicated for each example, and the Iso-codes for the languages can be found in the summarizing table in the Appendix. 
benefactive functions of other Arawakan languages (Aikhenvald, 2001). This kind of marking in Tariana is non-canonical when referring to a subject, and it represents an alternative to set $\mathrm{A}$ and set $\mathrm{B}$ marking. More precisely, there are three intransitive verb classes, one taking set $\mathrm{A}$, the second taking set $\mathrm{B}$, and the last one taking the object case or set B. Another particularity of Tariana is the general subject-predicate order, which is even maintained in the oblique subject constructions, as (15) illustrates:

(15) sõme di-na $\quad$ unina-pidana Tariana (Northern Arawakan)
a.lot 3SG.NF-OBJ thirsty-REM.P.REP
'He was very thirsty'
(lit. to him a lot of thirst, Aikhenvald, 2001: 180)

Tariana also employs the instrumental as an ergative marker on subjects, a construction, however, that does not seem to be related to DSM but rather to topicalization and ergative marking, similar to the closely related East Tucanoan languages, as Aikhenvald (1996: 101) has shown. Thus, Tariana has incorporated to some part the case system, or some characteristics of the case system of its contact language, which is a different case and will be briefly discussed in 4.2.

Garifuna (Munro, 2007, Haurholm-Larsen, 2016) presents, apart from prefixal and suffixal subject marking, three oblique cases for the subject of intransitive predicates, namely dative (16), instrumental (17), and benefactive (18):11

$\begin{array}{ll}\text { híruga-ti } & n \text {-ún } \\ \text { sad-M } & \text { 1SG-DAT }\end{array}$

Garifuna (Northern Arawakan)

'I am sad.'

(17) chú-ti $\quad t=a ́ u$

intelligent-M $\quad 3 \mathrm{~F}=\mathrm{INSTR}$

'She's intelligent.'

(18) uwadigia-ti n-uwágu

okay-M 1sg-BEN

'I'm okay.'

(Munro, 2007: 122-123)

Note that the examples of Garifuna also show a fossilized gender suffix, $-t i$ ' $M$ '. Usually, in this position there is a personal suffix for object reference in transitive constructions, or subject reference in set B constructions, or gender

11 Both authors do not specify if the use of the absolutive is possible for these verbs. 
agreement in these non-verbal (set B) predicates - $-t i{ }^{\prime} \mathrm{M}$ ' and - $t u$ ' $\mathrm{F}$ '. However, these morphemes are fossilized in the DSM construction and do not agree with the single argument. An alternative interpretation is that the construction still views the single argument as object and marks the gender reference to a dummy 3SG.M subject. In any case, the kind of oblique marking Garifuna prefers for each predicate presumably resides in the root's semantics. However, we do not have any information about the possible co-existence of set B marking and oblique marking for the same predicate in this language. Then we examine the predicates with oblique encoding and the semantic class they belong to.

Finally, Paresi seems to be the only language of the Southern Arawakan branch showing DSM, ${ }^{12}$ namely with the oblique marker - hiye, which is used as a locative with a very broad and extended general oblique interpretation (Silva, 2013). However, there is some confusion about the categorization of this morpheme. Brandão, for example, glosses this one morpheme as a locative (2014: 113) and as a benefactive (2014: 120)..$^{13}$

\subsection{The Semantics of DSM Predicates}

General typological studies on DSM (such as de Hoop and de Swart, 2008) show that generally, only a few predicates are concerned with DSM in a language. This is confirmed by the Arawakan languages, where we cannot find more than ten DSM predicates for each language, at least in our samples. Predicates showing DSM generally refer to psychological or physical states, and a few others refer to durative or mental states, for example to be an idiot or to be smart. Thirty meanings are covered by the DSM predicates of the nine languages of the sample. In this subsection, we present each language of our sample separately with respect to the kind of DSM predicates it shows, from the most to the least prototypical cases. The specific predicates are all listed in the Appendix. Mind that, in addition to these oblique markers, set $\mathrm{B}$ can be used as alternative construction for those languages that make use of set B patterns. Examples of the respective predicates that allow for this alternative construction are added throughout.

We begin with Piapoco, a language where the phenomenon of DSM is easily observable. According to Reinoso Galindo (1994, 1995, 2002) and to Durand (2013), there are numerous grammatical similarities between Piapoco and

12 Grammatical descriptions of other Southern Arawakan languages do not mention this phenomenon or do not offer examples showing without ambiguity that there is an oblique marking on the single argument of a monovalent predicate.

13 See also Silva (2013: 299), who calls it a "theme marker" - while the Arawakan benefactive postposition -ana (Brandão, 2014: 121, 158, 242, 343, etc. or Silva, 2013: 294) is also glossed and introduced as 'dative' (2014: 118). 
the other Arawakan languages from North Amazonia, apart from DSM. The sample obtained from these sources consists of five predicates that describe physical or physiological states and bodily sensations (for details see also the table in the Appendix): be hot (DAT/ABS/supess), sweat (DAT), be cold (SUPESS/ABS/DAT), shiver (SUPESS), be ill/ with a fever (ABS/SUPESS). Two of the verbs usually take dative marking for the unique argument, and three take superessive marking. In addition, the verbs of bodily sensation - 'be hot' and 'be cold' - can take either oblique or set B marking on their subject, with a meaning difference. These variant cases are discussed in the next subsection.

As for Kurripako and Baniwa do Içana - we consider that they belong to the same dialectal continuum (Ramirez, 2001: 40-41) - Taylor (1993) and Granadillo (2006) mention three stative verbs for which the subject is obligatorily marked by dative, a statement confirmed by Durand's data. ${ }^{14}$ The predicates refer to physical states and bodily sensations - be hot, be cold, sweat. While the first two seem to allow for variation with the set B, the last verb cannot take set B marking.

In Baniva del Guainía, subjects are marked by dative on eight predicates, mostly referring to physical and psychological states, including diseases (Aikhenvald, 1998: 363): be hot, be cold, boil, be hungry, be lazy, be ill/ have a fever, have a bad cold, be rude. We are not aware of any variation with set $B$ marking.

Concerning Tariana, predicates showing DSM are taken from Aikhenvald (2001). As mentioned above, Tariana has a general object marker -na 'овJ', possibly also analysed as a dative if we observe her data. This object marker is used with a number of predicates with a single argument. One example was (15), and another one follows in (19):
(19) amiri-ka-mha
du-na
Tariana (Northern Arawakan) drunk-DECL-PRES.NON.VIS 3SG.NF-OBJ
'She is drunk.'
(Aikhenvald, 2001: 180)

Three of the Tariana predicates with oblique subject marking, mhaisiki- 'hungry', mat $a$ - 'good' and ma:t $t i$ - 'bad', are supposedly all derived by the privative/ negative prefix $m(a)$ - (Michael and Granadillo (eds), 2014). This prefix is quite productive and pervasive in the Arawakan family (cf. Granadillo and Michael 2014), and triggers set B marking in many of the languages, since it functions as

\footnotetext{
14 Because Kurripako and Baniwa do Içana seem to behave exactly the same on DSM (Durand, 2013), they will appear in the same column in the Appendix.
} 
a verbalizer. ${ }^{15}$ For these three derived predicates, both types of marking can be encountered, set B as well as object 'ОВJ' or dative marking (Aikhenvald, 2001).

In Yukuna, in contrast to the other language descriptions, the predicates that show DSM are all analyzed as nominal predicates. Nominal stems, however, can be used as intransitive predicates, and a subgroup of them, takes dative marking on the unique argument: the deverbal nouns jima'a-ni 'hot/heat' and jipe'e-ni 'cold', the noun derived by privative, me'piji 'hunger/hungry', as well as the non-derived noun tapu 'sleep' (Schauer et al., 2005, Yucuna et al., 2003, Durand, 2013). These predicates were not found with other marking, be it set $\mathrm{B}$ or other oblique markings (compare table in Appendix). This situation is surprising, since in typical Arawakan morphology, all non-verbal predicates can have set B marking, that is a consequence of split intransitivity where the single argument of a non-verbal predication takes the set B. ${ }^{16}$ We consider it as an additional proof that Yukuna is turning into a set A-accusative language, since set $B$ is less and less used in other monovalent constructions. In any case, the word class categorization seems to be secondary; rather, it relies on the individual authors' preference. ${ }^{17}$ The adjective class is quite problematic in the family. They are attested in some languages (Launey, 2001) for Palikur) whereas others only have a handful of real adjectives (Aikhenvald for Baniwa del Guainía, Granadillo, 2006 for Kurripako), the rest being nominalized verbs. These latter are sometimes categorized by some researchers as adjectives. Furthermore, if Arawakan languages use nouns as predicates, they treat their stative subjects like objects by applying set B marking. Or, in the small class of these predicates, dative is applied in Yukuna.

$$
\begin{aligned}
& \text { jipe'e-ni } \quad \text { no-jlo } \\
& \text { cold-M 1SG-DAT } \\
& \text { 'I am cold.' }
\end{aligned}
$$

15 As in Kurripako, Paresi or Apurinã, for example, the affixation of the attributive $k a$ - to an active verb like 'walk' or 'run' leads to the use of the absolutive and denotes that the activity is done regularly, with ease or with pleasure. In other cases, as in Garifuna, Baure and Mojeño, the use of the absolutive is restricted to the privative/negative ma- (Durand, 2016: 348).

16 Nevertheless, nowadays, Arawakan languages often use a free pronoun instead of the absolutive for non-verbal predication.

17 The claim of a proper difference between Yukuna and the other languages cannot be held, because how can be proven that the stative concepts that are used as predicates are indeed nouns in Yukuna, but verbs in the other languages. In fact, the authors often rely on their translation language for the classification, or their translations lead other linguists to conclude the definite word class category. 
Garifuna is very special for presenting three oblique cases, namely dative, ${ }^{18}$ benefactive, and instrumental, for DSM. Remember that Garifuna is one of the languages with possible subject marking by a pronominal suffix, in other words, set B. Among oblique cases marking subjects, instrumental is by far used the most. According to Munro (2007), there are ten intransitive verbs with DSM in Garifuna. ${ }^{19}$ Relying on the data presented by the author, a few of these verbs can show standard agreement, such as the set $A$ or the set $B$, such as be sad' and 'be smart (Munro 2007:126-7). The verbs with instrumental, dative, or benefactive marking refer to various physical and physiological states, to bodily sensations, and to a number of mental states (see Appendix).

With regards to Paresi, Brandão (2014) declares that the subject of the predicates tiha 'cold' (21) and watya 'hot' (22) take locative/oblique marking on the single argument. They do not take benefactive marking, which could be expected - a recipient or dative could be semantically closer to a predicate than a locative: However, the benefactive in Paresi does not seem to be used for single stative arguments, but only in transitive contexts.

$$
\begin{array}{ll}
\text { tiha } & \text { wi }=\text { hiye } \\
\text { cold } & 1 \mathrm{PL}=\mathrm{BEN}[/ \mathrm{LOC}]
\end{array}
$$

Paresi (Southern Arawakan)

'It is cold for us.'

$$
\begin{array}{ll}
\text { watya } & \text { no=hiye } \\
\text { hot } & 1 \mathrm{SG}=\mathrm{BEN}[/ \mathrm{LOC}]
\end{array}
$$

'It is hot for me.'

(Brandão 2014: 236)

There has been no evidence about the possibility of using set B in these examples, alternatively.

After having reviewed the predicates that take object or oblique marking for subjects obligatorily, we now move on to variations in subject marking that may occur with a single predicate. We emphasize the fact that the content of the table found in the Appendix and the variety of the marking strategies are not exhaustive. ${ }^{20}$

18 This marker is similar to the ones used for benefactive constructions in other Arawakan languages (see Table 6 of Wise (1991: 271) for the morphophonological similarities between the dative -ún in Garifuna and the benefactives - min, -in and -in(o) respectively in Wayuunaiki, Wapishana and Terena).

19 Haurholm-Larsen $(2016: 90-91)$ does not give an exact number of these verbs.

20 In the future, we expect to find more of these predicates and also to get more information about variation and alternatives with absolute marking. 


\subsection{The Semantics of Oblique-Marked Predicates}

The marking of subjects by an oblique case is typologically not such a rare case; as Woolford (2008: 22) reminds us, dative marking often serves to indicate the goal or the experiencer. The oblique marking for predicates like kazalíni- 'cold' in Piapoco and Kurripako can be explained on these grounds, and the marking is lexically determined by the specific root. Woolford exemplifies a comparable situation in Icelandic:

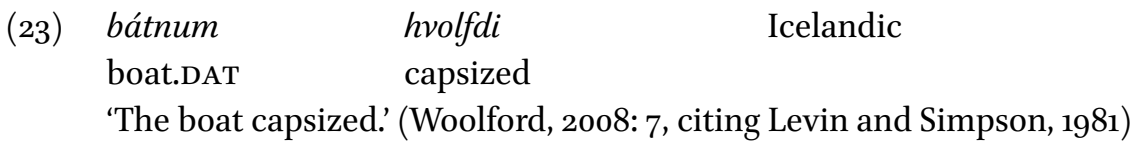

In the previous example, the boat is not actively involved by capsizing, but rather undergoing it, similar to an object - a comment that could be applied also to the set B marking. The choice of marking the subject by dative is therefore related to the degree of control the subject has over the state of affairs denoted by the verb. Examples of dative subjects can be found in Germanic languages, which lead to numerous publications concerning oblique subjects marking.

The situation gets more complex in Northern Arawakan languages, especially in Piapoco and Garifuna, where more than one oblique marker can be employed. Furthermore, in Piapoco, the same predicate can allow various types of subject marking, producing probably more or less subtle meaning differences. When one predicate allows more than one marking strategy, we have in Arawakan languages a semantically determined DSM - a phenomenon already observed by Aikhenvald for Baniva del Guainía (1998) - Warekena of Xie in her terminology - and Tariana (2001). In other words, not only this group of predicates selects one specific oblique marking, with a neutral meaning, but also set $\mathrm{B}$ and even other oblique markers. In contrast, languages, which allow only one type of marking, are characterized by a lexical DSM.

Getting back to the example of the heat predication, in Piapoco, it is possible to mark the subject in two ways: either by oblique (supess) or by set B marking, namely the subject being marked in the $\mathrm{O} /$ So slot. The two different constructions create a clear semantic difference, as the following contrastive examples show:
(24) úle-ka nua
Piapoco (Northern Arawakan)
hot-REAL B1SG
'I am hot (because of fever).' 
(25) úle-ka nu-wàli

hot-REAL ISG-SUPESS

'I feel hot (like feeling a hot wave when someone is opening the door of an overheated room).' (Durand, 2013)

In both cases, the sensation of heat is present and affects the entity as the experiencer. However, this impact manifests itself differently, which permits the speaker to better locate the heat source or understand the kind of heat sensation.

Similarly, we can observe that kazalini- 'cold', generally takes the superessive marker (26). Similarly to úle- 'hot', it can take two other markers, the dative (27) or the set B (28), with a small semantic difference in each case, as the following examples illustrate:

(26) kazalíni-ka nu-wàli

Piapoco (Northern Arawakan)

cold-REAL ISG-SUPESS

'I am cold.'

(27) kazalíni-ka nu-lí

cold-REAL 1SG-DAT

'I feel the cold / I am in the shade / it is cold where I am.'

(28) kazalíni-ka pía

cold-REAL B2SG

'You are cold (going out from cold water, a friend is freezing).'

(Durand, 2013)

The different interpretations observed from (26) through (28) refer less to the physical state itself than to the situational frame, the source of the sensation and the way it is perceived, although the canonical construction in (26) brings the most neutral meaning. In fact, the differences are quite subtle, and this explains probably why there are so many different translations in elicitation..$^{21}$ As for (28), set B construction does not indicate the feeling but physical traits easily observable (colour, rigidity of limbs, weak blood flow). Semantically determined DSM has also been noted in Kurripako in the speech of many people

\footnotetext{
21 We specify that it has nothing to do with where the speech act situation is. These different translations were all proposed by the speakers as situations fitted with the production of these sentences.
} 
over fifty years and people speaking different dialects (Durand, 2013). As for Piapoco, '(to be) hot due to illness' - something that can be confirmed simply by checking one's temperature - is marked by set B. Moreover, it is very easy to find statements with reference to a $3^{\text {rd }}$ person when talking about the climate, as in hámuni 'it is hot', hápeni 'it is cold', with the set B marker of third person $-n i$. Even if DSM does not concern these two last predicates, the fact that they use the set $B$ for other physical phenomena confirms our hypothesis on the use of the set B in DSM.

In Baniva del Guainía, we also find different possibilities of either marking the unique stative argument of this group of predicates by the dative postposition -yue 'to, for' for more temporary/punctual states (29), which is the most frequent marking, and by set $\mathrm{B}$ for a more durative interpretation (30), as reported by Aikhenvald (1998).

nu-yue mawali
1SG-DAT hungry
'I am hungry (just now).

Baniva del Guainía (Northern Arawakan) 'I am hungry (just now).'

(Aikhenvald, 1998: 363)

(30) mawali-na

hungry-[B]1SG

'I am hungry (permanently, or over a continuous life-span).'

(Aikhenvald, 1998: 363)

As you can notice, (29) and (30) are constructed on the basis of the same lexical root that allows two kinds of marking. In other cases, the same or similar physical or physiological state shows two types of marking strategies, but in each case, the lexical root is a different one. We could not find the meaning difference between the two constructions in Baniwa, contrasted in (31) - (32) and (33) - (34). Compare:

(31) aashapi-na

Baniva del Guainía (Northern Arawakan)

hot-B1SG

'I am hot.'

(32) asharewa no-yue-je

hot 1SG-DAT-PAUS

'I am hot.'

(33) meepi-na

cold/bored-B1sG

'I am cold/bored.' 


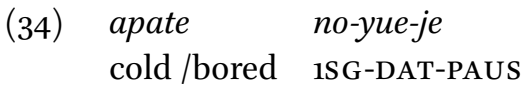

'I am cold/bored.'

(Durand, 2013)

In Tariana, we find some similarities in the semantics of the constructions, but also some semantic and morphological differences (Aikhenvald, 2001). More precisely, there is an aspectual distinction between predicates with marking by -na 'овJ' and other types of marking. In the following examples, the construction with -na marking (35) implies a durative event, whereas the one with a verbal construction (36) - here marked by an applicative (instrumental) on the verb - implies a punctual event. ${ }^{22}$

$$
\begin{array}{ll}
\text { adaki-mha } & n u-n a \\
\text { feverish-PRES.NON.vis } & 1 \text { ig-OBJ }
\end{array}
$$

'I have been feverish.'

\author{
Tariana (Northern Arawakan)
}

(over a lengthy period of time)

Another construction in Tariana that originates from an instrumental construction and marks the subject (ergative), is apparently the result of structural borrowing from East Tucanoan languages with which Tariana has been in extensive contact. We will come back to this issue again in 4.2 below.

(36) nuha adaki-ne-mha

ISG feverish-INSTR-PRES.NON.VIS

'I am feverish.' (right now, for a short time) (Aikhenvald, 2001: 195)

Furthermore, for some predicates in Tariana, there is no applicative marking necessary, and the predicate can occur in two construction types with different semantics: object marking for punctual states (37) and unmarked arguments for durative states (38), another case of semantically determined DSM:

(37) wa-na âे ma:i-ma-naka

Tariana (Northern Arawakan)

1PL-OBJ here bad-EXC-PRES.VIS

'We are here in a very bad way.'

(lit. here it is bad to us)

\footnotetext{
22 We need further investigation on applicative arguments in Southern Arawakan languages, in order to include them into the analysis of DSM, since the languages in the South are particularly known for rich applicative morphology.
} 


$\begin{array}{llll}\text { waha ma:i-ma-naka } & \text { wa-numa } & \text { sewite } \\ \text { we bad-EXC-PRES.VIS } & \text { [A]1PL-mouth } & \text { quick.CL:ANIM } \\ \text { 'We are bad and gossipy.' } & & \end{array}$

(lit. we are bad and our mouth is quick, Aikhenvald, 2001: 181)

These two examples are too marginal to be relevant for the present section; however, they show that the distribution between oblique marking and nonmarking can be motivated by aspect.

It has already been noticed by many authors that there can be variations in marking of the same predicate; in particular in studies on Hindi (as e.g. Montaut, 1997 and de Hoop and Narasimhan, 2014). In Hindi, the subject can either be marked by nominative, ergative, or even by dative, as the following examples show:

$$
\begin{array}{ll}
\text { raam }=n e & \text { chiikh-aa } \\
\text { raam=ERG } & \text { scream-PFV.SG.M }
\end{array}
$$

Hindi (Indo-European)

'Raam screamed (purposefully).'

(40) raam- $\emptyset \quad$ chiikh-aa

raam-NOM scream-PFV.sG.M

'Raam screamed.'

(41) raam=ne ghar jaa-naa hae raam=ERG home go-INF be.PRS.3SG

'Raam wants to go home.'

(42) raam=ko ghar jaa-naa hae

raam=DAT home go-INF be.PRS.3SG

'Raam wants to/has to go home.'

(de Hoop and Narasimhan, 2014: 67-69)

As shown by (39) through (42), ergative evokes a more agentive (purposeful) reading, nominative seems to be neutral, while the dative case is used where either volition or obligation is involved, and where we may assume that the subject is less agent-like. Even if the phenomenon exposed here is DAM rather than DSM, it illustrates perfectly the interest, on a semantico-pragmatic perspective, of using complementary marking.

In spite of the interest of the issue, we have to keep in mind that semantically determined DSM is actually restricted to very few intransitive predicates, while the majority of them have only one kind of marking. If we make an 
example with dative marking in Piapoco for a verb taking set B arguments, then the sentence is automatically corrected and reinterpreted, with some actual dative relation. Compare therefore the attempt of constructing a dative subject in (44) to the model construction with set B in (43) and the resolution in (45):
43) ka-dapule-ka núa ATTR-sleep-REAL BISG
'I am sleepy'.
(44) *ka-dapule-ka nu-lí ATTR-Sleep-REAL 1SG-DAT

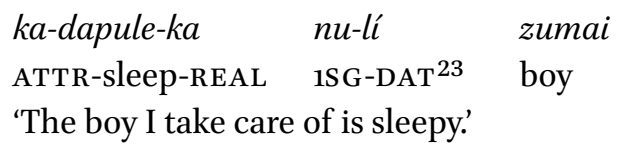

Piapoco (Northern Arawakan)

(lit. the boy of mine is sleepy, Durand, 2013)

Piapoco is quite strict about which verb shows variation in oblique marking. Apart from the group of predicates with oblique marking, the only exception for verbs that canonically take the set B seems to be kauleka- 'ill', which may either take oblique or set B marking, as illustrated in (46) and (47). In this case, the superessive marking seems to mark an inchoative state, while set $B$ refers to a durative state.

$$
\begin{aligned}
& \text { (47) kauleka-ka nu-wàli } \\
& \text { ill-REAL ISG-SUPESS } \\
& \text { 'I fell ill (after having done some activity).' }
\end{aligned}
$$

Piapoco (Northern Arawakan)

ill-REAL BISG

'I am ill.'

Let us now situate this type of DSM within linguistic typology. Numerous studies had the goal to determine some universal constraints for differential marking of arguments. An outstanding example is Silverstein (1976) and his

\footnotetext{
23 We specify that the -li morpheme 'DAT' is not used for the possession. This is why the speaker here proposed this translation involving the caring of someone.
} 
referential hierarchy, explaining that the properties of the referent - human, animate or inanimate - leads to one particular marking. For example, in Aranda, a Pama-Nyungan language of Australia, the ergative case is used only for the first person pronouns and for inanimates. Witzlack-Makarevich (2011: 7588) lists five categories related to these referential properties, animacy, humanness, definiteness, specificity and person. These properties explain the difference of treatment of different referents, which is why it does not apply to Arawakan languages.

Indeed, for these latter ones, DSM has been observed with /+human/ arguments encoded generally by first or second person pronouns or affixes. The first point is easily explainable. Since the predicates with oblique marking describe psychological/physiological sensations, they would not be used for inanimate entities. For animate non-human entities, it would depend of the empathy of the speaker. For the use of first and second person pronouns/affixes, it is linked to the method we used to collect data. Third person pronouns/affixes are sometimes not expressed, especially when they are coreferent with an NP, which is why most of our data are constituted of first and second person pronouns/affixes. Further investigations are needed to complete the actual data.

Witzlack-Makarevich (2011: 91) argues that the use of various oblique markings for a single predicate can be observed in languages where case marking is simultaneously determined by a number of parameters and quotes Dolakha Newari, Spanish and, of course, Hindi. In other words, if we showed in this subsection the importance of semantic parameters for DSM in Arawakan languages, we still need further investigation to see if there is a web of referential properties impacting it. More precisely, it will be necessary to see if this phenomenon depends on features like affectedness. Indeed, we have seen in Piapoco that set $B$ has been used for more physical states than the dative or the superessive, and that, in Tariana, the duration of affectedness depends on the use of the instrumental or the objective case.

\subsection{Summary}

In a nutshell, we have presented the fact that DSM exists in the Arawakan language family, but also that the phenomenon is generally restricted to a very small group of stative predicates, which are listed in the table in the Appendix. In Yukuna, apparently, only non-verbal predicates are affected. The predominant postposition that is found for oblique marking of subjects is the dative/ benefactive, but others are also found: instrumental and superessive. Generally, the single oblique-marked argument is postposed to the predicate. Then furthermore, even fewer predicates exhibit the meaningful variation between different types of marking (set B, different types of obliques). The motivation 
for the different choices is semantic, generally the set B marking referring to rather long-term states, whereas oblique constructions tend to trigger a punctual interpretation. Both types of marking have in common that the subject is less agent-like and therefore marked like one kind of object and not by canonical subject marking in the prefix position, as we find it typically with transitive verbs.

As we have shown, quite a number of Northern Arawakan languages make use of DSM with one or more oblique markers. Since we know that some of these languages have also been subject to more or less intensive language contact (e.g. Tariana in the Vaupés basin, and Garifuna with various languages throughout the history), we have looked for the presence of DSM in Arawakan languages in diachronic data. Tariana is an interesting case, since its case system has partly been borrowed from Eastern Tucanoan languages. The intensive contact that Tariana has had with other languages in the region has led to structural borrowing, as reported in the literature (Aikhenvald, 1996, 2002).

\subsection{Diachronic Evidence of DSM in the Arawakan Language Family}

In Section 3, we have sketched the distribution of DSM in the Arawakan language family. DSM is found in at least eight Arawakan languages, i.e. a fifth of the languages of the family. Such a relatively wide distribution makes us think that this characteristic is an inherited language internal feature. Apart from this, however, the considerable geographical distance between languages like Garifuna in the Caribbean and Paresi in the Xingu in Brazil, and the larger distribution among languages in the area of the border of Colombia, Venezuela, and Brazil (north-western Amazonia), seems to infirm the hypothesis of language contact. In order to test these two possibilities, in this section, we emphasize on the diachronic comparison of Garifuna and its ancestor language of the $17^{\text {th }}$ century, Island Carib, on the one hand, and of contemporary Achagua and $18^{\text {th }}$ century Achagua, on the other hand. We argue that the inherited feature is the most credible hypothesis, relying on the diachronic data of two languages. In any case, it will be interesting for us to take a look at the older sources of Arawakan languages to find out if the construction already existed then, in fact, in times where language contact with Spanish was not so visible in the grammatical structure of the languages yet.

Our data of Island Carib from the $17^{\text {th }}$ century were collected by Father Breton (1999[1665]), and the contemporary Garifuna data were taken from Suazo 
(2001) and Munro (2007). It is true that the scarce data on Island Carib does not permit us to make very strong claims about the general characteristics of intransitive predicates. However, by collecting the predicates referring to physiological, physical, or mental states from Breton's (1999[1665]) dictionary, we find evidence for the presence of dative and instrumental marking on the subject, thus some evidence of the early existence of DSM.

The following two examples demonstrate that dative marking occurs in both languages throughout the different centuries as the marking of the second object of bivalent verbs, as in (48) and (50), and in oblique subject marking, as in (49) and (51). ${ }^{24}$

$\begin{array}{lll}\text { kanoúbouna-ti } & n \text {-óne } & \text { Island Carib (Northern Arawakan), XVII } \\ \text { scare-[B]33G.M } & \text { ISG-DAT } & \end{array}$

'He scares me.'

(49) araógoüa-ti n-óne

sweat-M ISG-DAT

'I am sweating.'

(Breton, 1999 [1665], our glosses)

(50) hanufun(a/e)-ti n-un Garifuna (Northern Arawakan), XXI

scare-[в]3SG.M ISG-DAT

'He scares me.'

(51) harauga-ti $\quad n$-un
sweat-M 1SG-DAT
'I am sweating.'

(Suazo, 2001, our glosses)

In these comparable examples, we can see that the same predicate 'sweat' takes oblique subject marking in the language variety of the $17^{\text {th }}$ century and its descendent language of the $21^{\text {st }}$ century. Both constructions are also comparable in other respects, as e.g. the presence of a fossilized third person suffix on the predicates with oblique subject marking (examples (49) and (51)). We can thus state that the phenomenon of dative marking on the single argument of a stative predicate already existed in Island Carib.

Furthermore, listing the intransitive predicates with oblique subject marking in Father Breton's dictionary (1999 [1665]) and comparing them to the ones

24 Note again the appearance of the masculine suffix on predicates with DSM, as in (49) and (51). Compare also (53), where the personal suffix has gender reference to the absolutive subject. 
identified in Munro's (2007) paper, we obtain a similar number of occurrences. Apparently, also instrumental marking on a subject was already used in Island Carib. This can be illustrated by the predicate 'ashamed' in (52). We compare this construction with example (53) from contemporary Garifuna, where the same predicate takes set B - unfortunately, we could not find predicates needing the instrumental in both varieties:

$\begin{array}{ll}\text { abouri-ti } & n \text {-áo } \\ \text { ashamed-M } & \text { 1SG-INSTR }\end{array}$

'I am ashamed.'

(53) haburi-ti-na ashamed-M-[B]1SG 'I am ashamed.'
Island Carib (Northern Arawakan), XVII (Breton, 1999 [1665], our glosses)
Garifuna (Northern Arawakan), XXI

(Suazo, 2001, our glosses)

We have also examined data on $18^{\text {th }}$ century collected by the Jesuits de Neira and Rivero (1928 [1762]). First of all, Achagua, in this historical source, is clearly a split intransitive language with set $B$ marking on the predicate. ${ }^{25}$ In the grammatical description, only one intransitive predicate with dative marking on the subject occurs (54), as opposed to various examples with set B marking.

$\begin{array}{ll}\text { cibiu } & \text { nu-riu } \\ \text { hurt } 1 S G-D A T & \\ \text { 'I am hurt/ it irritates me.' }\end{array}$

Achagua (Northern Arawakan), XVIII

(de Neira and Rivero, 1928 [1762]: 87, our glosses) ${ }^{26}$

We can only speculate that due to the similarity of the dative marker -riu in the historical data and the marker - $l i$ in the contemporary Achagua language, there were also other similarities in structure. We cannot conclude from the available data to which extent the dative marking was already acceptable

25 Contrary to contemporary Achagua that uses absolutive pronouns postponed to the predicate for object marking, Achagua from the $18^{\text {th }}$ century seems to employ suffixes for the absolutive, as in the example viuna 'I am' (Neira and Rivero, 1928 [1762]: 10), where the suffix $-n a$ is the absolutive of first person. This kind of morphological absolutive seems to have got lost.

26 Note that in alternative orthographies, different graphemes are used, as e.g. here $c$ for $[\mathrm{k}]$; usually $c$ before a high vowel would refer to [s]. 
for oblique subjects in older data, or the possibilities of several oblique marking. ${ }^{27}$

Considering historical data, we do find enough evidence to at least suppose that a few predicates showed DSM already in times before extensive contact with Spanish, a language which could have some influence on DSM on account of its copular construction for some stative verbs - constructions that will be presented in the next section. It may have been a grammatical feature that developed further throughout the centuries. In this case, it could have been a characteristic of Proto-Arawak or an innovation of one Arawakan language that had been diffused within the family afterwards. The idea of language contact therefore moves a bit to the background. Nonetheless, we will discuss this possibility in the upcoming subsection.

\subsection{Which Impact could Language Contact have had for DSM in Arawakan?}

The question if DSM is an inherited feature or result of language contact was raised by Granadillo (2006). In her study of Kurripako, she wanted to explain the existence of this particular group of verbs with oblique marking on the subject, as in the following example:

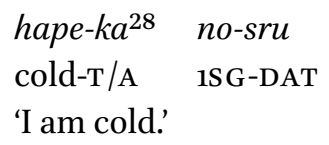

Kurripako (Northern Arawakan)

(Granadillo 2006: 116)

Granadillo worked with the speakers' intuitions with respect to the construction, let the bilingual Kurripako translate into Spanish and found that they tend to translate the dative suffix -sru as the Spanish verb tener 'have'. ${ }^{29}$ This makes -sru suspicious for her to be a result of a Spanish loan translation, since Spanish uses this verb in constructions with a number of physical or physiological states, as for example in tengo frío 'I am cold, lit. I have cold'. This hypothesis has not been proven and will not be discussed much more in this paper. The dative construction is not only used by young bilinguals, but it is pervasive in Kurripako and related languages. Granadillo (2006: 117) mentions herself

27 For the same reason, we could not compare those data with data on actual Achagua, for which the authors (Wilson, 1992, Meléndez, 1998) do not mention DSM.

28 We specify that this $-k a$ suffix is a thematic suffix, stem closing, or even transitivizing (verbalizing here).

29 The dative is sometimes used in Northern Arawakan languages to encode the possession, thus this interpretation. However, we have not found yet a link between the encoding of possession and DSM. 
that the tendency may also be to replace dative constructions by set B constructions, meaning the formerly dative subject turns into (grammaticalizes into) a proper set $\mathrm{B}$ subject.

However, language contact did have quite some impact on a number of Arawakan languages. Famous cases are indeed Garifuna with Cariban and European languages (see de Pury, 2000), and of course, the languages of the Vaupés region, in particular Tariana (Aikhenvald, 2002), having been in long-term contact and exchange with Tucanoan languages. It has been well described how much the structure of the languages in contact changed and the languages copied features from one to the other language and vice versa.

Nonetheless, there are two major counter-arguments concerning the hypothesis of language contact. On the one hand, the use of oblique marking for the single argument is not common in South American languages, at least this is what the literature tells us - for example, Aikhenvald (2002: 101) qualifies the system of non-subject case marking of Tukano languages as "uncommon". On the other hand, the phenomena of oblique marking or the like in other possible contact languages are radically different from what we see in Arawakan languages. For example, we find some systems where set $\mathrm{A}$ and the ergative are both used for the single argument, as in Kashibo-Katataibo, a Panoan language (Valle, 2011). Or in Ka'apor, a Tupi-Guarani language of Northern Brazil, the particle $k e$ 'affected' can be used on some subjects, possibly in a comparable way to an oblique marking for subjects. However, we do not find cases of dative or instrumental marking on subjects in non-related and possible contact languages. It does not seems to be any evidence for this type of oblique marking on subjects even within the Cariban languages, the ones who could have influenced Island Carib, the ancestor language of Garifuna. In fact, the only languages with this kind of DSM which could have been in contact with Arawakan languages are the Tucanoan languages Coreguaje (Cook and Levinsohn, 1885: 113), Siona (Wheeler, 1987: 124-6), and Murui, a Witoto language spoken in West Colombia (Aikhenvald, 2010: 35; Guérin et al., 2016). ${ }^{30}$ In these languages, polysemic markers, employed also as instrumental, may be used to mark the single argument of an intransitive verb. Nevertheless, apart from this similarity in the pattern, DSM in these languages shows great morphosyntactic differences in comparison with what we see in Arawakan languages, since the markers used to code DSM can code core grammatical relations, as the subject role, and are being employed as focus or defocus markers. As we can see in the next

30 It is almost impossible to find data for the East Tucanoan languages that Tariana definitely has been in contact with, since these almost extinct languages offer poor documentation. 
examples of Siona, the - $b i$ marker can be used to mark the subject of transitive (56) and intransitive verbs (57). However, in cases such as non-verbal predication (58), it is not used. Finally, when affixed to another argument than the subject, in (59) as an instrumental, it functions as a defocus marker (Wheeler, 1987). ${ }^{31}$

(56) ja'an bain-bi güeso hua'i-re ai-ñe-ña. Siona(West Tucanoan) DEM people-SBJ capybara meat-DO eat-PST.PL-SEP

'This people eat capybara meat.'

(Wheeler, 1987: 120)

(57) sense jubë-bi ai jëja tërë-jën eta-huë. pig herd-sBJ lot loudly grumble-sım.PL go.out-PST.PL 'The pig herd went out grumbling loudly.'

(Wheeler, 1987: 124-125)

(58) ta'ye-jei-ye-reba

surpass-DER-NMLZ.NF-PREC

'He is the most eminent chief.'

$\begin{array}{ll}\text { ëjaguë } & \text { ba’-ji. } \\ \text { chief } & \text { be-PRs.M }\end{array}$

(Wheeler, 1987: 131)
huë-re
hua'ti-bi
huä̈-ё
black.agouti-Do
machete-INSTR
kill-PST.1SG

'I killed the black agouti with a machete.'

(Wheeler, 1987: 125)

In the Arawakan languages, DSM is much more reduced and does not imply syntactic roles or (de)focus functions when they are attributed to the single argument.

Only for Tariana, can we state that the case system has partly been influenced by the contact of languages (East Tucanoan), as Aikhenvald (1996) reports. In this specific case, alternatively to the object marker -na that can be used in DSM, there is an instrumental -ne that has the function to mark ergative subjects as well as instrumental objects, similar to what is illustrated for Siona above in (56) through (59). This is, however, not the same as the oblique marking on the single argument that we have described in this paper. This particular strategy may or may not be the result of language contact; it can also be an "independent development" (Aikhenvald 1996: 100) or an "innovation" of Tariana (ibid. 101), as Aikhenvald claims.

\footnotetext{
31 You will see that the Tucanoan language presented is also structurally completely distinct from Arawakan, see e.g. person marking by suffixation, fused with tense markers.
} 
(6o) da:pi-kha-ne nuya-pidena Tariana (Northern Arawakan) vine-CL:CURV-INSTR [A]3SGF+hit-PART water-LOC

'She (the snake woman) hit with a vine on the water.' (Aikhenvald, 1996: 100)

(61)

$\begin{array}{llll}\text { pa:tfi-ne } & \text { na-ka-pidena } & \text { na-sita } & \text { nekwe-se-se-pidena } \\ \text { other-ERG } & {[\mathrm{A}] 3_{3} \text { PL-see-PART }} & {[\mathrm{A}] 3_{\text {PL-finish }}} & {[\mathrm{A}] 3_{\text {PL+among-CONTR-LOC-PART }}} \\ \text { di-mara } & \text { di-nu } & \text { di-a } & \\ \text { float } & {[\mathrm{A}] 3_{\text {SGNF-come }}} & {[\mathrm{A}] 3_{\text {SGNF-go }}}\end{array}$

'Others (in contrast to the liar) finally did see (the otter) moving floating toward them.'

(Aikhenvald, 1996: 101)

Furthermore, if we examine the distribution of Arawakan languages showing DSM, it appears that except for the Rio Negro languages, it would have been very difficult to have language contact, since a rare phenomenon would not appear in three distinct points within the same linguistic family. Indeed, the authors who worked on Arawak migrations (Hill and Santos-Granero, 2010, Walker and Ribeiro, 2011) state all that the Arawak originated from a midAmazonian position and then migrated to North and South. Then, non-Arawak groups installed themselves between Arawak groups, such as the Tupi between Paresi and Arawakan languages more to the North. Consequently, Paresi, Garifuna and the Rio Negro languages would not have been in contact after their split. To resume, DSM would be an innovation from a long time ago, at least several thousand years ago, in other words from Proto-Arawak, before the separation of North and South Arawakan languages; an innovation then preserved in the languages presented here. Then, the DSM phenomenon would have been modified in a number of ways, as in the type of oblique marker used dative for the majority, instrumental and benefactive in Garifuna -, and lost in the majority of the family, more precisely the four fifths.

In a last point, we reject the hypothesis of DSM being a recent innovation for nearly the same reasons as concerning language contact. It would imply three distinct points of appearance whereas DSM is quite a rare phenomenon in South America. Furthermore, based on the semantic motivations presented in Section 3, even if DSM can be useful, it is not an essential tool, which is why this phenomenon has been abandoned in the major part of Arawak family.

\section{5}

\section{Conclusion}

DSM refers to a variable phenomenon inside the Arawakan family. The predicates that manifest its phenomenon represent a reduced class, less than ten. 
Furthermore, they are more varied in Garifuna where they can express durative states, contrary to other Arawakan languages where they express only psychological and physiological punctual states. Of all the oblique cases implicated, the dative is most common whereas the instrumental or the superessive are specifics to some languages; for instance, Piapoco uses the superessive whereas we can find the instrumental and the benefactive in Garifuna.

Moreover, this study on DSM presented the use of different markings for a single predicate, that is, a complex system of complementarity and/or competition between set $B$ and oblique cases. This system permits the speaker to express various semantic subtleties on the psychological/physiological state and its cause. In other words, it is not another strategy to replace a loss of split intransitivity. On the contrary, it combines perfectly with it.

Concerning the origin of DSM, it is quite certain that it is an inherited feature to the Arawakan family, a case confirmed to some degree by data found in Island Carib and in Old Achagua. The hypothesis of language contact has been discarded because of the geographic distance, and especially because the morphosyntactic features of DSM were too different in order to find any comparable system that could have had an impact. Nevertheless, it is still not clear if DSM appeared in Proto-Arawak and then remained in the eight languages already mentioned, or if it appears later in three points: in Island Carib, in Paresi and in the Alto Rio Negro where it would have been expanding through language contact between Piapoco, Kurripako, Tariana, Yukuna, Baniwa del Guainía, and old Achagua.

\section{Appendix}

We recapitulate here all the predicates showing DSM according to their semantic fields and to the oblique marking they usually take. We insist on the fact that, concerning languages where semantically determined DSM has been observed, the use of set B for these predicates is potentially possible with all of them, even if we only put here set B with the verbs for which it has been attested in the examples. Further investigation is needed for languages where it has not been observed, as in Yukuna and Paresi. All of the languages in the table are accompanied by their Iso codes. 


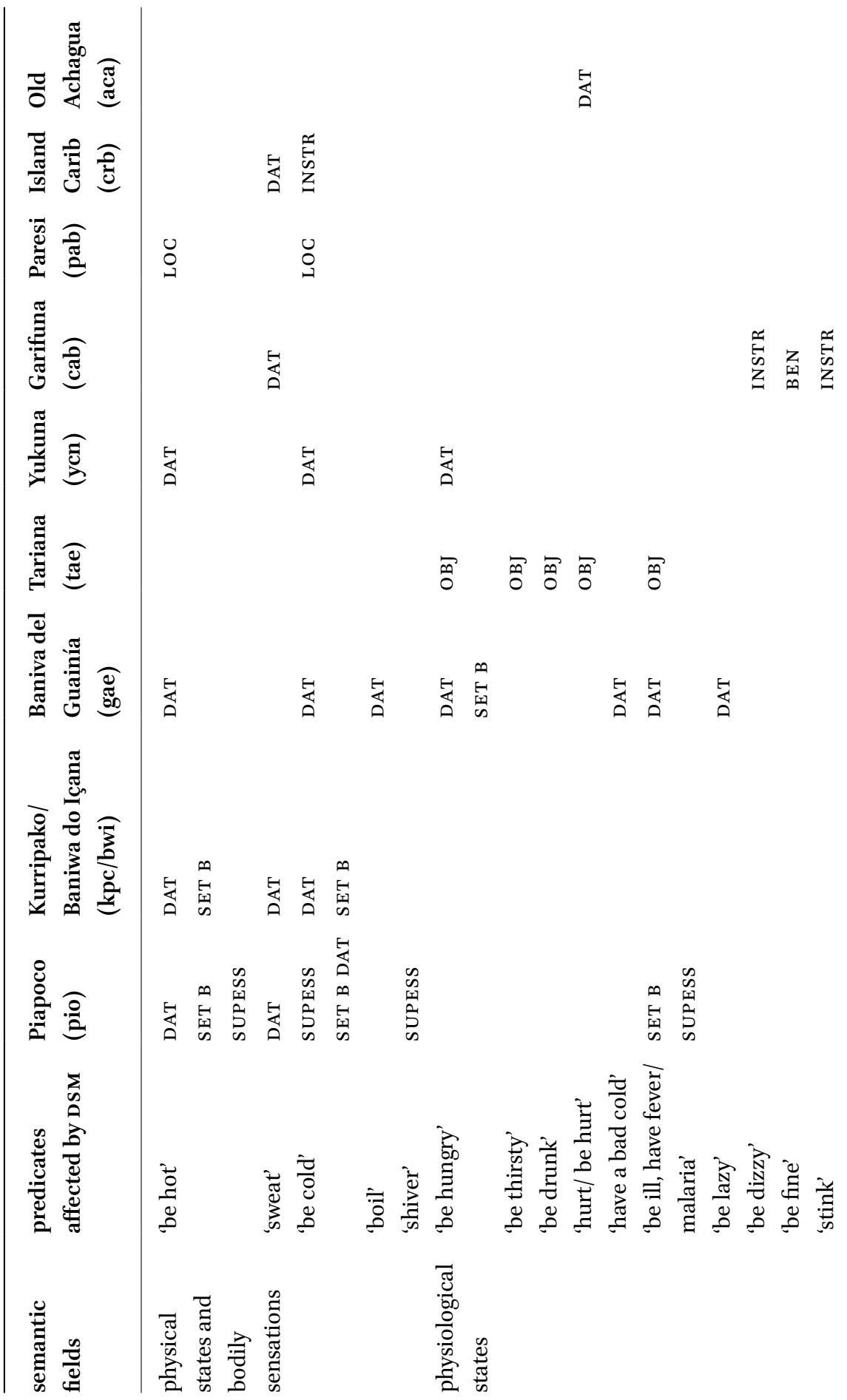




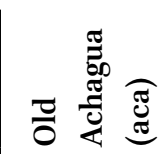

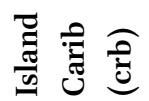

离

氶

冚

:

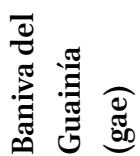

范

范

竞

总

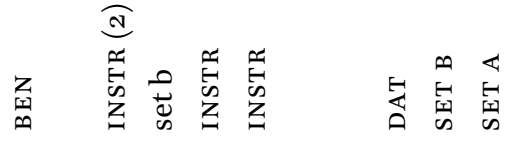

它

舟

$\underset{1}{\stackrel{0}{5}}$

皇

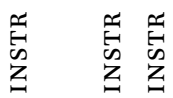

$\stackrel{\infty}{0}$

它

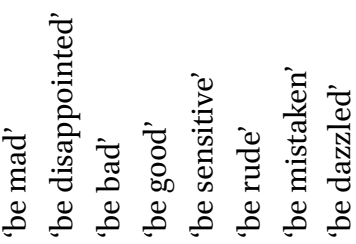

离 


\section{Abbreviations}

\begin{tabular}{|c|c|}
\hline$A=$ & set A \\
\hline ANIM = & animate \\
\hline ATT R $=$ & attributive \\
\hline $\mathrm{B}=$ & set B \\
\hline $\mathrm{BEN}=$ & benefactive \\
\hline CAUS $=$ & causative \\
\hline CURV = & curvilinear \\
\hline $\mathrm{CL}=$ & class marker \\
\hline $\mathrm{CON}=$ & connector \\
\hline CONTR $=$ & contrast \\
\hline $\mathrm{DAT}=$ & dative \\
\hline DECL $=$ & declarative \\
\hline $\mathrm{DEM}=$ & demonstrative \\
\hline $\mathrm{DER}=$ & derivation \\
\hline $\mathrm{DO}=$ & direct object \\
\hline $\mathrm{EP}=$ & epenthetic \\
\hline $\mathrm{ERG}=$ & ergative \\
\hline $\mathrm{EXC}=$ & excessive \\
\hline $\mathrm{F}=$ & feminine \\
\hline $\mathrm{FUT}=$ & future \\
\hline $\mathrm{INF}=$ & infinitive \\
\hline $\mathrm{IPFV}=$ & imperfective \\
\hline INSTR $=$ & instrumental \\
\hline $\mathrm{INTJ}=$ & interjection \\
\hline $\mathrm{LK}=$ & linker \\
\hline $\mathrm{LOC}=$ & locative \\
\hline$M=$ & masculine \\
\hline $\mathrm{NF}=$ & non-feminine \\
\hline $\mathrm{NMLZ}=$ & nominalizer \\
\hline $\mathrm{NOM}=$ & set A \\
\hline овJ = & object \\
\hline PASS $=$ & passive \\
\hline PAUS $=$ & pause marker \\
\hline $\mathrm{PART}=$ & particule \\
\hline $\mathrm{PFV}=$ & perfective \\
\hline $\mathrm{PL}=$ & plural \\
\hline $\mathrm{PREC}=$ & precisely \\
\hline PRES.VIS = & present visual \\
\hline
\end{tabular}




$\begin{array}{ll}\text { PRES.NON.VIS }= & \text { present non-visual } \\ \text { PRS }= & \text { present } \\ \text { PST }= & \text { past } \\ \text { REAL }= & \text { realis } \\ \text { REM.P.REP }= & \text { remote past reported } \\ \text { SBJ }= & \text { subject } \\ \text { SEP }= & \text { perspective of seperation } \\ \text { SG }= & \text { singular } \\ \text { SIM }= & \text { simultaneity } \\ \text { SUPESS } & \text { superessive } \\ \text { T/A }= & \text { tense/aspect } \\ \text { TRS }= & \text { transitional } \\ \text { V }= & \text { verb }\end{array}$

\section{References}

Aikhenvald, Alexandra Y. 1998. Warekena. In Desmond Derbyshire and Geoffrey Pullum (eds.), Handbook of Amazonian Languages, Vol. IV, 225-439. Berlin: Mouton de Gruyter. DOI: 10.1515/9783110822120?nosfx=y.

Aikhenvald, Alexandra Y. 1999. The Arawak language family. In Robert M.W. Dixon and Alexandra Y. Aikhenvald (eds.), The Amazonian Languages, 65-105. Cambridge: Cambridge University Press.

Aikhenvald, Alexandra Y. 2001. Verb types, non-canonically marked arguments and grammatical relations: A Tariana perspective. In Alexandra Y. Aikhenvald, Robert M.W. Dixon and Masayuki Onishi (eds.), Noncanonically marked subjects and objects, 177-199. Amsterdam:John Benjamins. DoI: 10.1075/tsl.46.o8aik.

Aikhenvald, Alexandra Y. 2002. Language contact in Amazonia. Oxford: Oxford University Press.

Aikhenvald, Alexandra Y. 2010. Language contact and pragmatic notions: Tariana in its multilingual context. In José Camacho, Rodrigo Gutiérrez-Bravo, and Liliana Sánchez (eds.), Information Structure in Indigenous Languages of the Americas: Syntactic Approaches. 225, 17-38. Berlin: Mouton de Gruyter. DoI: 10.1515/9783110228533.17.

Aikhenvald, Alexandra Y., Robert M.W. Dixon and Masayuki Onishi, (eds.). 2001. Noncanonical marking of subjects and objects (Vol. 46). John Benjamins Publishing.

Brandão, Ana Paula Barros. 2014. A reference grammar of Paresi-Haliti (Arawak). PhD dissertation, University of Austin, Texas.

Breton, Raymond (Rev. Père), 1999 [1665]. Dictionnaire caraïbe - français. New edition supervised by Marina Besada Paisa (CELIA). Paris: Karthala/IRD. 
Brown, James and Tyler Peterson. 2007. Grammaticalization and strategies in resolving subject marking paradoxes: the case of Tsimshianic. In Helen de Hoop and Peter de Swart (eds.), Studies In Natural Language And Linguistic Theory 72, 223-245 Dordrecht: Springer. DoI: 10.1007/978-1-4020-6497-5_10.

Cabana, Nasle Maria. 2014. Marcação diferencial do sujeito na lingua ka'apor, Revista Linguística 10(2), 180-198. Available at: http://www.revistalinguistica.letras.ufrj.br/ index.php/revistalinguistica/issue/view/1.

Cook, Dorothy M. and Stephen H. Levinsohn. 1985. Coreguaje: Domains of Focus Markers. In Ruth M. Brend (ed.), From phonology to discourse: studies in six Colombian languages, 91-116. Dallas: SIL. Available at: http://www.sil.org/resources/archives/3927.

Danielsen, Swintha. 2007. Baure: An Arawak Language of Bolivia. Indigenous Languages of Latin America (ILLA) 6. Leiden: cNWs.

Danielsen, Swintha. 2011a. The personal paradigms in Baure and other Southern Arawakan languages. In Antoine Guillaume and Francoise Rose (eds.), Argumentcoding systems in Bolivian Amazonian languages. International Journal of American Linguistics 77(4), 495-520. DOI: 10.1086/662154.

Danielsen, Swintha. 2011b. The grammaticalization of adpositions into valency increasing verbal affixes in Arawakan languages. Presentation held at the ssila annual meeting in Pittsburg, during the LSA conference, 6 of January, 2011.

Danielsen, Swintha, Michael Dunn and Pieter Muysken. 2011. The Spread of the Arawakan Languages: A View from Structural Phylogenetics. In Jonathan Hill and Alf Hornborg (eds.), Ethnicity in Ancient Amazonia: Reconstructing past identities from archaeology, linguistics, and ethnohistory, 173-195. Boulder, CO: University Press of Colorado.

de Hoop, Helen and Bhuvana Narasimhan, 2008. Ergative case marking in Hindi. In de Hoop and de Swart (eds.), Differential subject marking, 63-78. Dordrecht: Springer.

de Hoop, Helen and Peter de Swart. 2008. Differential subject marking. Dordrecht: Springer.

de Neira, Alonso and Juan Rivero, S.J. 1762. Arte y Vocabulario de la Lengua Achagua. Doctrina Christiana de uno y otro sexo é instrucción de Cathecumenos. Sacado de lo que trabajaron los Padres Alonso de Neiray Juan Ribero de la Compañia de Jesus. Trasuntado en el Pueblo de San Juan Franco Regis Año 1762. Ms.

de Pury, Sybille. 200o. Les verbes empruntés au français par le garifuna: des verbes d'état? Amerindia 25, 49-64.

de Swart, Peter and Helen de Hoop. 2007. Semantic aspects of differential object marking. In Estela Puig-Waldmüller (ed.), Proceedings of Sinn und Bedeutung 11, 568-581.

Durand, Tom. 2012. Field data collected in Peru from July 2012 till August 2012.

Durand, Tom. 2013. Field data collected in Colombia and Venezuela from August 2013 till October 2013 . 
Durand, Tom. 2016. L'intransitivité scindée dans les langues arawak. PhD dissertation. INALCO: Paris.

Facundes, Sidney da Silva, 200o. The language of the Apurinã people of Brasil (Maipure/ Arawak). Buffalo: University of New York. Available at: http://www.etnolinguistica .org/tese:facundes-200o.

Gilij, Filippo S. 1780-1784. Sagio di storia americana; o sia, storia naturale, civile e sacra de regni, e delle provincie spagnuole di Terra-Ferma nell' America Meridionale descritto dall' abate F. S. Gilij (Vols. 1-4). Rome: Perigio. (Republished as Gilij 1965).

Givón, Talmy. 2001. Syntax: an introduction, Vol. I. Amsterdam/ Philadelphia: John Benjamins. DOI: 10.1075/z.syn1.

Gildea, Spike (ed.). 200o. Reconstructing Grammar: Comparative Linguistics and Grammaticalization Theory. Amsterdam/Philadelphia: John Benjamins. Dor: 10.1075/ tsl.43.

Goergens, Anne. 2011. Stability and change in alignment systems: a study of agreement patterns in Arawakan languages. Bachelor thesis. Lund: University of Lund.

González Ñáñez, Omar. 2005. Lenguas y nombres de lenguas usados para designer a los pueblos Maipure Arawakos de la Región del Alto Río Negro, Suramérica. Boletín de Lingüística, 23, Universidad Central de Venezuela, Caracas, Venezuela, 106-116. Available at: http://www.scielo.org.ve/scielo.php?script=sci_arttextandpid=So798 -97092005000100006 .

Granadillo, Tania. 2006. An ethnographic account of language documentation among the Kurripako of Venezuela. PhD dissertation, University of Arizona. Available at: http://arizona.openrepository.com/arizona/bitstream/10150/195916/1/azu_etd_ 160o_sip1_m.pdf.

Granadillo, Tania and Lev Michael (eds.). 2014. Negation in Arawak Languages. B RILL. DOI: $10.1163 / 9789004257023$.

Guérin, Valérie, Simon Overall and Alexandra Aikhenvald (organizers). 2016. Grammatical categories and information structure, Special Workshop of the Language and Culture Research Centre, LCRC, June 29-30. Ms.

Hanson, Rebecca, 2010. A Grammar of Yine (Piro). Melbourne: La Trobe University. Available at: http://arrow.latrobe.edu.au:808o/vital/access/manager/Repository/ latrobe: 37856 .

Haurholm-Larsen, Steffen, 2016. A Grammar of Garifuna. Bern: University of Bern. Available at: https://www.academia.edu/30535982/A_Grammar_of_Garifuna.

Hill, Jonathan D. and Fernando Santos-Granero. (eds.). 2002. Comparative Arawakan histories: rethinking language family and culture area in Amazonia. Urban: University of Illinois Press. DOI: 10.1111/j.1548-1352.2010.01112.x.

Levin, Lori and Jane Simpson. 1981. Quirky Case and lexical representations of Icelandic verbs, Chicago Linguistics Society 17, 185-196. 
Lewis, M. Paul, Gary F. Simons, and Charles D. Fennig (eds.). 2016. Ethnologue: Languages of the World, Nineteenth edition. Dallas, Texas: sIL International. Online version: http://www.ethnologue.com.

Meléndez, Miguel Angel Lozano. 1998. La lengua achagua, estudio gramatical. Lenguas Aborígenes de Colombia, Descripciones, 11. Santafé de Bogotá: CCE LA, UNIANDES.

Montaut, Annie. 1997. Constructions expérientielles et possessives en hindi. Faits de langues 10, 229-236. DoI: 10.3406/flang.1997.1190.

Munro, Pamela. 2007. Oblique subjects in Garifuna. In Peter K. Austin and Andrew Simpson (eds.), Endangered Languages. Linguistische Berichte Sonderheft 14, 113142. Hamburg: Helmut Buske Verlag.

Ramirez, Henri. 1992. Le Bahuana, une nouvelle langue de la famille Arawak. Paris: Chantiers Amerindia 17(1).

Ramirez, Henri. 2001. Línguas Arawak da Amazônia setentrional: comparação e descrição. Manaus: Editora da Universidade do Amazonas.

Reinoso Galindo, Andrés E. 1994. Estructuras sintácticas de la oración en el piapoco, BIFEA 23(3), 481-508.

Reinoso Galindo, Andrés E. 1995. Diccionario Piapoco - Español, Español - Piapoco. Bogota: Fundación Etnollano.

Reinoso Galindo, Andrés E. 2002. Elementos para una gramática de la lengua piapoco. Bogota: Ministerio de cultura.

Schauer, Stanley, Junia G. Schauer, Eladio Yukuna, and Walter Yukuna. 2005. Meke kemakánaka puráka'aloji wapura'akó chu, eyá karíwana chu. Diccionario bilingüe yukuna-español español-yukuna. Bogota: Editorial Buena Semilla.

Silva, Glauber Romling da. 2013. Morfossintaxe da lingua paresi-haliti (arawak). PhD dissertation, Universidade Federal do Rio de Janeiro.

Silverstein, Michael. 1976. Hierarchy of Features and Ergativity. In Robert M.W. Dixon (ed.), Grammatical Categories in Australian Languages, 112-71. Canberra: Australian National University.

Sheil, Christine. 2013. The Status of Person Markers in Garifuna. Unpublished qualifying paper, UC Berkeley. Available at: http://linguistics.berkeley.edu/ csheil/The StatusofPersonMarkersinGarifuna.pdf.

Suazo, Salvador. 2001. De caribe a garifuna: un estudio comparativo de la lengua caribe del siglo XVII y del garifuna actual. Paris: A.E.A.

Taylor, Gerald. 1993. Breve léxico da lingua baniwa do Içana. Paris: CNRs.

Valle, Daniel. 2011. Differential subject marking triggered by information structure. Memorias del V Congreso de Idiomas Indigenas de Latinoamérica, October 6-8th, University of Texas, Austin.

Walker, Robert, Ribeiro, Lincoln. 2011. Bayesian phylogeography of the Arawak expansion in lowland South America. Proceedings of the Royal Society B - Biological Sciences, 278(1718), 2562-2567. DOI : 10.1098/rspb.2010.2579. 
Wheeler, Alva. 1987. Gantëya bain (El pueblo siona del Río Putumayo, Colombia), Vol. II. Bogota: Instituto Lingüistico de Verano.

Wilson, Peter J. 1992. Una descripción preliminar de la gramática de la lengua achagua (arawak). Translation and redaction by Stephen H. Levinsohn. Bogotá: Instituto Lingüístico de Verano.

Wise, Mary Ruth. 1991. Morfosintaxis comparativa y subagrupaciones de las lenguas arawakas maipurán. Revista Latinoamericana de Estudios Etnolingüísticos 6, 259-282.

Witzlack-Makarevich, Alena. 2011. Typological Variation of Grammatical Relations. PhD dissertation. Leipzig: University of Leipzig.

Woolford, Ellen. 2008. Differential Subject Marking at Argument Structure, Syntax, and PF, de Hoop and de Swart (eds.), 17-40. DoI: 10.1007/978-1-4020-6497-5_2.

Yucuna, Milciades, Edilberto Yucuna, Rey Yucuna and Laurent Fontaine. 2003. Mythe des Karipú Lakena (Mythe d'origine du monde). Available at: http://site.laurentfon taine.free.fr/Transcriptions-yucuna/Recits/Kamejeya_MilciadesandEdilberto/YU CUNA_Milciades-Karipu_Lakena_2003-08.pdf. 